\title{
Dental Microwear From Natufian Hunter-Gatherers and Early Neolithic Farmers: Comparisons Within and Between Samples
}

\author{
Patrick Mahoney* \\ Department of Archaeology, University of Sheffield, Sheffield S1 4ET, UK

\begin{abstract}
KEY WORDS diet; functional morphology; facet nine
\end{abstract}
\begin{abstract}
Microwear patterns from Natufian hunter-gatherers $(12,500-10,250 \mathrm{bp})$ and early Neolithic $(10,250-7,500 \mathrm{bp})$ farmers from northern Israel are correlated with location on facet nine and related to an archaeologically suggested change in food preparation. Casts of permanent second mandibular molars are examined with a scanning electron microscope at a magnification of $500 \times$. Digitized micrographs are taken from the upper and lower part of facet nine. Microwear patterns are recorded with an image-analysis computer program and compared within and between samples, using univariate and multivariate analyses. Comparisons within samples reveal a greater frequency of pits on the lower part of the facet among the farmers, compared to the
\end{abstract}

The development from a Natufian (12,500-10,250 bp) to early Neolithic $(10,250-7,500 \mathrm{bp})$ culture in the Levant led to changes in settlement patterns, architecture, tools, and biological characteristics and demographic structure of the people (Bar Yosef, 1992, 1998; Bar Yosef and Belfer-Cohen, 1989; Eshed et al., 2004a,b; Garrod, 1957; Henry, 1989; Kenyon, 1957; Mellaart, 1975; Moore, 1982; Rollefson and Kohler-Röllefson, 1989; Wright, 1993). The early prepottery Neolithic culture (PPN), which is subdivided into an initial (PPNA, 10,250-9,400 bp), middle (PPNB, 9,400-8,100 bp), and late phase (PPNC, 8,100-7,500 bp), was also characterized by dietary developments. Animal and plant foods that were hunted and gathered by the Natufians were increasingly farmed during the Neolithic (Clutton-Brock, 1971; Colledge, 1994; Legge, 1996; Martin, 1994; Willcox, 1998). These dietary developments were detected in human skeletons, through $\mathrm{Sr}-\mathrm{Ca}$ ratios and changes in the prevalence of dental caries (Sillen, 1981, 1986; Smith et al., 1984). Dietary abrasiveness was also inferred from dental macrowear in Natufian populations (Smith, 1972; Smith et al., 1984). Yet few have made direct comparisons between periods in order to infer dietary texture (hardness vs. softness).

The aim of the present study is to infer dietary texture during the Natufian to early Neolithic development in northern Israel from microscopic dental pits and scratches (dental microwear). Prior studies demonstrated the efficacy of dental microwear for dietary inference among early hominids (Grine, 1981, 1987; Grine and Kay, 1987; Lalueza and Pérez-Pérez, 1993; Lalueza et al., 1996; Puech, 1992; Puech et al., 1983; Ungar and Grine, 1991; Walker, 1979), fossil primates (Teaford, 1993; Teaford et al., 1996; Ungar, 1996), and archaeologi- upper part. Microwear does not vary over the facet among the hunter-gatherers. Comparisons between samples reveal larger dental pits (length and width) and wider scratches among the farmers at the bottom of the facet, compared to the hunter-gatherers. Microwear does not vary between samples at the top of the facet. The microwear patterns suggest that the Natufian to early Neolithic development led to a harder diet, and this is related to an archaeologically suggested change in food processing. The harder diet of the early farmers may have required higher bite forces that were exerted at the bottom of facet nine, in the basin of the tooth. Am J Phys Anthropol 130:308-319, 2006. @ 2006 Wiley-Liss, Inc.

cal samples of modern humans (Blaeur and Rose, 1982; Bullington, 1991; Gordon, 1986; Harmon and Rose, 1988; Molleson and Jones, 1991; Molleson et al., 1993; Pastor, 1993; Puech, 1976; Schmidt, 2001; Teaford, 1991; Teaford et al., 2001; Ungar and Spencer, 1999).

Dental microwear is caused by hard abrasive particles as they are moved over the tooth surface during chewing. Some plant foods contain these particles, known as phytoliths (Baker et al., 1959; Piperno, 1988), and these are implicated as a cause of both scratches (Mills, 1955; Teaford, 1993; Walker and Teaford, 1989; Walker et al., 1978) and pits (Gügel et al., 2001). Hard nonfood particles, such as dietary grit, can produce a similar effect (Covert and Kay, 1981; Peters, 1982; Teaford and Lytle, 1996).

Another inferred cause of microwear is tooth-on-tooth contact (Every, 1974). Such contact might remove enamel flakes (Rensberger, 1978), hydroxyapatite crystallites (Teaford and Runestad, 1992; Teaford and Walker, 1984), prism-sized chips (Rensberger, 2000; Walker, 1984), or anomalous ameloblast-sized enamel that proj-

Grant sponsor: Arts and Humanities Research Council, United Kingdom.

*Correspondence to: Patrick Mahoney, Department of Archaeology, University of Sheffield, North Gate House, West Street, Sheffield, England S1 4ET. E-mail: pmahoney@sheffield.ac.uk

Received 13 September 2004; accepted 4 April 2005.

DOI 10.1002/ajpa.20311

Published online 4 January 2006 in Wiley InterScience (www.interscience.wiley.com). 
ects beyond the surrounding surface (Boyde, 1989). This idea is supported by the presence of dental pits on the teeth of stillborn guinea pigs, and between interproximal surfaces, because neither are exposed to the abrasive effects of food (Teaford and Walker, 1983; Pérez-Pérez et al., 2003). Potentially, microwear size measurements may be able to identify tooth-on-tooth contact, given that enamel prisms and ameloblasts have average dimensions (4-5 $\mu \mathrm{m}$; Eisenmann, 1998; Moss-Salentijn and Henrdricks-Klyvert, 1990).

Based on these causal agents, studies on extant species correlated variations in microwear patterns (frequency and size of pits and scratches) with dietary abrasiveness and texture. For instance, an increase in dietary abrasiveness can produce more scratches (e.g., Teaford and Lytle, 1996; Walker et al., 1978), while harder diets can generate more pits (e.g., Teaford and Walker, 1984; Teaford, 1985; Strait, 1993). Similar correlations were inferred from microwear size measurements. For example, harder foods can cause wider pits (Teaford and Oyen, 1989; Teaford and Runestad, 1992), while introducing larger particles into a diet can result in wider scratches (Ungar, 1992, 1994). However, the type and amount of force that is exerted during chewing may influence all of these measurements. For instance, a model of microwear formation processes developed in chimpanzees suggests that more shear and compression may increase scratch length and width, while a reduction in shear and increase in compression might increase pit size (Gordon, 1982).

\section{THE PREHISTORIC ECONOMY}

Natufian hunter-gatherers from northern Israel, around the upper/lower Galilee and Mount Carmel region, exploited a diverse range of potentially edible animal and plant foods from both sedentary and more mobile settlements (e.g., Bar Yosef, 1998; see also Fig. 1). Animal foods included gazelle, pig, deer, cattle, caprine, and fish at sites bordering Lake Hulleh (Bar Yosef, 1993; Martin, 1994; Noy, 1993; Perrot, 1993). Plant foods included wild barley, lentils, and nuts (Henry, 1989; Hopf and Bar Yosef, 1987; Noy et al., 1973; Perrot, 1993; Willcox, 1999), some of which might have been prepared for consumption through dehusking and grinding (e.g., Hillman, 1984, 1985), using mortars, pestles, and grinding stones that were constructed from basalt, limestone, and sandstone (Bar Yosef, 1991, 1993; Henry, 1989; Noy, 1993; Perrot, 1960, 1993; Stekelis and Yizraeli, 1963).

Early Neolithic people in the study area practiced a hunting-farming economy from increasingly sedentary settlements (e.g., Garfinkel, 1987). As with the Natufians, animal foods included wild gazelle, cattle, and deer (Gopher, 1997; Hershkovitz and Galil, 1990), though caprine may have been under a degree of human control at some sites (Galil et al., 1993). Unlike the Natufians, some plant foods, such as emmer wheat, broad beans, and lentils, were cultivated (Galil, 1993; Galil et al., 1993; Garfinkel, 1987) and perhaps prepared for consumption using the large grinding tools (querns/grinding slabs) that are a characteristic of early Neolithic people (Galil et al., 1993; Garfinkel, 1993; Gopher, 1997; GoringMorris, 1995; Wright, 1993).

The economy of the Natufian and early Neolithic people in the study area differs in two ways. First, the sheer volume of potentially edible plant remains at some Neolithic sites, such as emmer wheat and pulses, suggests a dietary

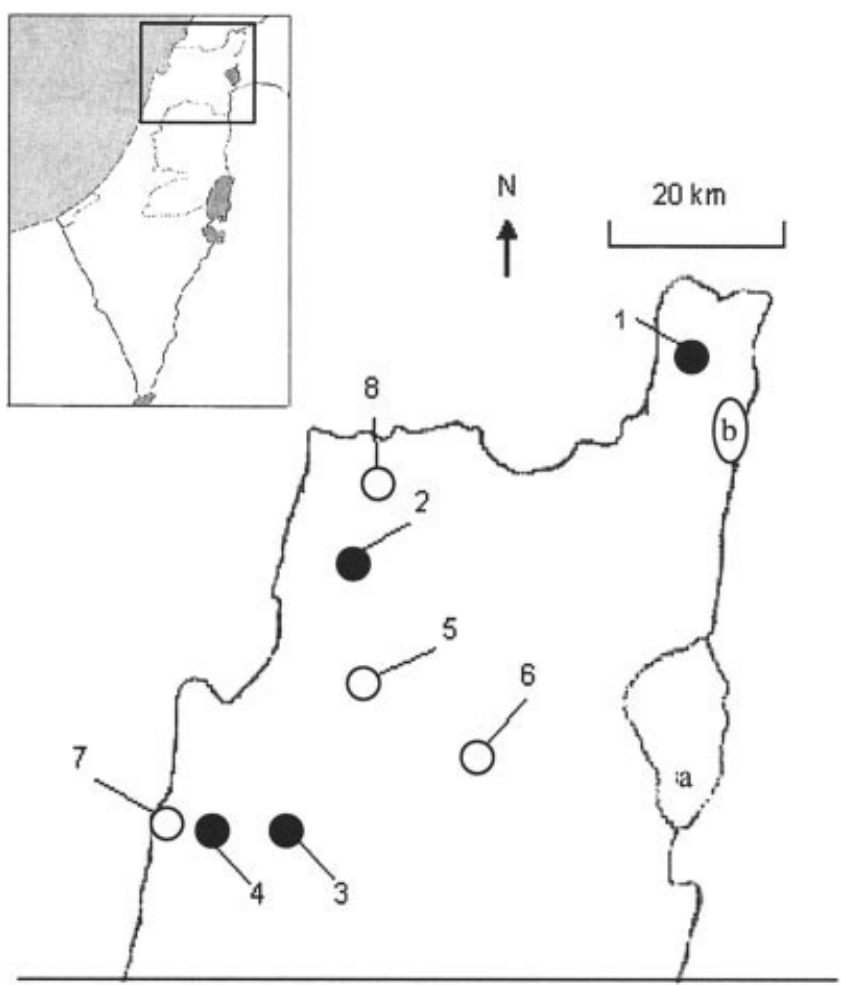

Natufian Site $=$ Early Neolithic Site $=0$

$1=$ Ein Mallaha, 2 = Hayonim Cave, $3=$ Raqefet

Cave, $4=$ Nahal Oren, $5=$ Yiftahel, $6=$ Kfar

Hahoresh, 7 = Atlit Yam, $8=$ Horvat Galil, $\mathrm{a}=$

$$
\text { Lake Tiberias, } \mathrm{b}=\text { Lake Hulleh (drained) }
$$

Fig. 1. Location of archaeological sites in study area. Inset: Israel and Negev, West Bank, and Gaza Strip. Northern Israel (study area) is framed in inset.

emphasis toward farmed foods (Galil, 1993; Galil et al., 1993; Garfinkel, 1987). Second, the increase in size of stone tools at some Neolithic sites might reflect an increased emphasis toward grinding plant foods, so that their nutritional value could be maximized, perhaps because local cultivable land was overexploited (Wright, 1993).

\section{Hypothesis}

More stone-ground foods could have increased the amount of hard abrasives entering the early Neolithic diet. This study tests the hypothesis that a harder, more abrasive diet will produce larger and more frequent pits. Given that the seed coats of plants such as wheat are removed prior to consumption (Hillman, 1985), and that these contain phytoliths (Piperno, 1988), changes in scratch frequency and scratch length are not anticipated.

\section{MATERIALS}

The second mandibular molar was selected from 60 human skeletons recovered from eight archaeological 


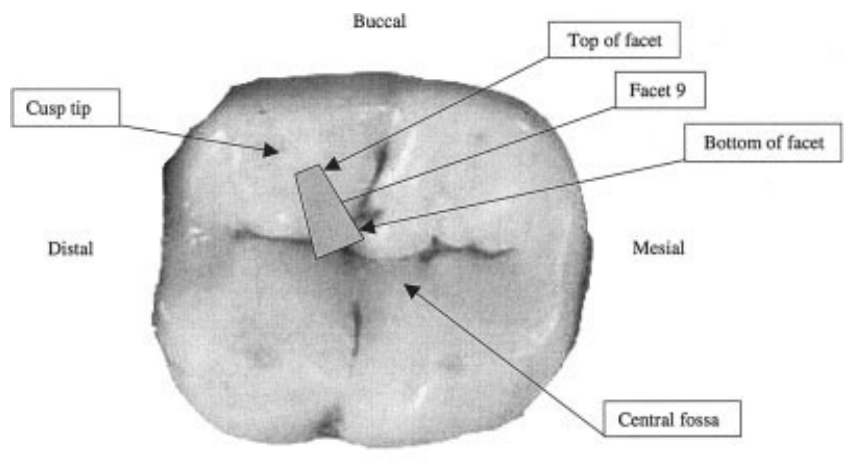

Lingual

Fig. 2. Occlusal surface of left second mandibular molar. Facet 9 is located on distal-buccal cusp. Top of facet is located beneath cusp tip. Bottom of facet is located toward central - fossa.

sites in the study area (Fig. 1). Thirty skeletons date from early and late in the Natufian period (Hayonim Cave, $\mathrm{n}=16$; Ein Mallaha, $\mathrm{n}=8$; Nahal Oren Terrace, $\mathrm{n}=4$; and Raqefet Cave, $\mathrm{n}=2$ ) and 30 date from the $\mathrm{PPNB} / \mathrm{C}$ periods (Kfar Hahoresh, $\mathrm{n}=19$; Yiftahel, $\mathrm{n}=3$; Horvat Galil, $\mathrm{n}=2$; and Atlit Yam, $\mathrm{n}=6$ ). Each site has several stratigraphic layers that include well-documented evidence for Natufian (Bar Yosef, 1991; Noy, 1989; Noy and Higgs, 1971; Perrot, 1993; Valla et al., 1998) and Neolithic (Galil, 1993; Garfinkel, 1993; Gopher, 1997; Goring Morris, 2000; Hershkovitz et al., 1986; Hershkovitz and Galil, 1990; Hershkovitz and Gopher, 1988) habitation. The skeletons are curated at the Sackler School of Medicine, Tel Aviv University.

\section{METHODS}

\section{Developing a methodology}

Microwear patterns are influenced by variations in shearing and compressive forces, along the tooth row, between shearing and grinding facets, and between the upper and lower part of shearing facets (Bullington, 1991; Gordon, 1982; King et al., 1999; Mahoney, 2006; Robson and Young, 1990; Teaford, 1985; Teaford and Oyen, 1989). Preliminary studies indicate that microwear patterns may also vary over grinding facets (Mahoney, 2006). The present study focuses on a grinding facet, facet nine, which is located on the occlusal surface of the disto-buccal cusp on the second mandibular molar (Maier and Schneck, 1982; see also Fig. 2). Facet nine experiences both compression and shear during chewing (Kay and Hiiemae, 1974). If these forces varied over the facet among Natufian and early Neolithic people, influencing microwear, then perhaps this might also influence microwear comparisons between huntergatherers and farmers. This would be of particular interest in a diet-microwear study because it might be possible to choose a location on the facet that would optimize microwear variations between samples.

The analyses involve two stages. In the first stage, microwear patterns are compared between the upper and lower part of facet nine among hunter-gatherers and farmers. The aim is to establish if microwear varies over the facet (within-samples comparison; see Table 1). Microwear patterns are then compared between huntergatherers and farmers, at the upper part of the facet and then the lower part. The aim is to evaluate if micro-
TABLE 1. Aims in first stage of analysis

Aim Hunter-gatherers
$\begin{aligned} & \text { Does microwear } \\ & \text { vary over facet 9? }\end{aligned}$
$\begin{aligned} & \text { Does microwear } \\ & \text { vary between } \\ & \text { hunter-gatherers } \\ & \text { and farmers? }\end{aligned}$

wear variations between the two groups are influenced by dental location (between-samples comparison). The skeletal material used in the first stage of the analysis (hunter-gatherers, $\mathrm{n}=10$; farmers, $\mathrm{n}=10$ ) is a subset of the sample used in stage two, and they were chosen because they produced a micrograph at both the top and bottom of the facet. In the second stage of the analysis, the sample size is increased (hunter-gatherers, $\mathrm{n}=30$; farmers, $\mathrm{n}=30$ ), and a comparison is conducted between samples at a dental location chosen on the basis of the results from stage one.

Prior research showed no relationship between microwear and the age, sex, and habitat (coastal sites vs. inland) of samples when subdivided by period (Mahoney, 2003). Others also showed no relationship between microwear and sex (King et al., 1999; Nystrom et al., 2004; Pérez-Pérez et al., 1994), age (King et al., 1999; Nystrom et al., 2004), or location of an archaeological site (Schmidt, 2001). Therefore, the data were pooled for the present study (i.e., early and late Natufian combined, and PPNB and PPNC combined).

\section{The microwear procedure}

All contaminants were removed from the dental surface using ethanol and cotton wool, and an impression was taken using a rubber-based addition-curing silicone (Lightbody ${ }^{\circledR}$ President Jet, Coltène). Following Nystrom et al. (2004), facet nine was excised from each impression using a scalpel, thus reducing scanning electron microscope (SEM) image distortion due to angulation of the tooth surface (Gordon, 1982). The excised facet was surrounded with dental putty (President Putty ${ }^{\circledR}$, Coltène) to create a depression. An epoxy resin (Araldite MY 753, hardener HY 956, Ciba-Geigy) was poured into the depression to produce a cast of the facet. Each cast was mounted on an aluminium stub after its base had been coated with an electrode paint (Electrodag $1415 \mathrm{M}$ ). The top and bottom of each facet was marked on each stub to help orient the facet in the SEM specimen chamber. The stub was placed into a Sputter Coating Unit (EMSCOPE SC500) for $3 \mathrm{~min}$ to receive a $20-\mathrm{nm}$ coating of gold-palladium. Digitized micrographs were taken using an SEM (CAMSCAN) at the Sorby Centre for Electron Microscopy and Microanalysis, University of Sheffield. The CAMSCAN was operated in the secondary electron emission mode, with a spot size of 3.0 and an accelerating voltage of $15 \mathrm{kV}$. Dental casts were orientated perpendicular (tilt angle $0^{\circ}$ ) to the primary beam. For each cast, the entire facet was examined at a magnification of $20 \times$. The length of the bottom edge of the facet was measured on the SEM viewing screen, using a 
ruler. After the midpoint was identified, magnification was increased to $500 \times$, and a micrograph was taken. Where a facet terminated in a point, the apex of the point was chosen. The procedure was repeated at the top of the facet, although ultimately the dental locations varied between individuals because of differences in facet size. Each digitized micrograph $(700 \times 500$ pixels $)$ represented approximately $0.03 \mathrm{~mm}^{2}$ of the tooth surface.

A 4:1 length-to-width ratio was used to distinguish between pits and scratches, which were measured and counted using a semiautomated image-analysis computer program (Microware version 3.0 Beta; Ungar, 1997). The program was operated with a resolution of $0.333 \mu \mathrm{m}$ per pixel (dots per inch [DPI] 152). Eight microwear variables were created automatically by Microware 3.0 for each micrograph, and these were used in all analyses: total number of features (i.e., total number of pits and scratches combined), mean number of pits, mean number of scratches, percent pits, mean length and width of pits, and mean length and width of scratches.

\section{Statistical procedure for stage one}

Within samples. A paired-samples $t$-test was used to compare microwear from the top of the facet with the bottom, in the Natufian and then the early Neolithic sample. This test assumes that the differences calculated for each pair have a normal distribution (Norusis, 1991), and this was checked with a Kolmogorov-Smirnov goodness-of-fit-test (KS-test). In addition, each variable was either log- or square root-transformed (percent pits arcsine-transformed; Zar, 1999) to reduce the influence of univariate outlying data.

Between samples. An independent-samples $t$-test was chosen to compare microwear across the two time periods, at the top of the facet and then at the bottom. The test assumes that the data have a normal distribution, and that the two groups have an approximately equal variance. The assumptions were checked with a KS-test and Levene's test, respectively. Each variable also received the appropriate transformation (see above). All statistical tests were conducted using SPSS 11 for Windows. The significance level was set at $P \leq 0.05$.

\section{Statistical procedure for stage two}

Between samples. A discriminant function analysis (DFA) was chosen to evaluate how well the (significant) microwear patterns characterize the two groups, and to assess how each (significant) microwear variable contributes to between-samples variation. In a DFA, a new variable is created from a linear combination of independent variables (i.e., microwear variables), named a function. Each independent variable is assigned a coefficient, which is selected to maximize the difference between previously defined groups (i.e., hunter-gatherers or farmers). Each individual is assigned a score from the function. The score is used to place the individual in one of the two groups. The more successful the function, the more cases are correctly classified. These scores can also be plotted, which gives a visual appreciation of the results.

In addition to the classification process and a plot of the discriminating scores, a DFA can be evaluated through a significance test, measures of variance, and standardized canonical correlation coefficients. A chisquare transformation of Wilks' lambda tests the null hypothesis that there is no difference between group means. However, a significant result could, if interpreted in isolation, be misleading. Small differences between means may be statistically significant, yet this may not necessarily reflect good discrimination (Norusis, 1993).

Good discrimination can be evaluated through the eigen value (E) and canonical correlation (U). The E value is the ratio of the between-groups sum of squares to within groups, and the higher the $\mathrm{E}$ value, the better the function's discriminating power (Norusis, 1993). E values of $>0.4$ are considered eligible for interpretation (Norusis, 1991). The $U$ value is the ratio of between groups to total variance, calculated from the scores on the function (Norusis, 1993). Correlation is measured between 1 and 0 , and a high value indicates a successful function.

Each variable's relative contribution to the function can be assessed through the standardized canonical correlation coefficients. These are the constants by which each variable is multiplied in order to construct the function; the larger the coefficient, the greater the variable's contribution to the function.

A DFA assumes multivariate normality and homogeneity of the variance-covariance matrices (Tabachnick and Fidell, 2001), which were checked using Box's M test. Though not formally required by the DFA assumptions, the test's discriminating power was improved through further data screening (Tabachnick and Fidell, 2001). Univariate outliers were screened as above. A multivariate outlier, to which the DFA is particularly sensitive, was identified through a Mahalanobis measure of distance and removed. Inspection of bivariate scatter plots and a correlation matrix showed that the data satisfied requirements for linearity and multicolinearity, respectively. Throughout, a stepwise DFA was chosen because there was no reason to assign one of the (significant) independent variables higher priority than another.

\section{RESULTS Stage one}

Within samples. Statistically significant differences were found for one variable, i.e., percent pits. The percentage of pits increased from the top $(38.8 \%)$ to the bottom of the facet $(50.3 \%)$ among the farmers $(P=0.043)$. An equivalent comparison indicated no significant differences between the top and bottom of the facet among the hunter-gatherers. Table 2 provides descriptive statistics for the first stage of the analysis. Table 3 shows the statistical results for the within-samples comparison. Figure 3. shows representative microwear from the upper and lower part of the facet.

Between samples. Statistically significant differences were found for three variables, pit length, pit width, and scratch width, when the comparison was undertaken at the bottom of the facet. Dental pits were larger among farmers compared to hunter-gatherers (length, 3.9-7.2 $\mu \mathrm{m}$, $P<0.000$; width, 2.0-3.2 $\mu \mathrm{m}, P<0.000)$. Scratches were also wider among farmers than hunter-gatherers (1.4$1.7 \mu \mathrm{m}, P=0.015)$. Microwear patterns did not vary between hunter-gatherers and farmers when the comparison was undertaken at the top of the facet. Table 4 shows the statistical results for the between-samples comparison.

Discussion of stage one results. Even though only one microwear variable could distinguish between the upper and lower part of the facet among the farmers, 
TABLE 2. Mean values and standard deviations (SD) for first stage of analysis ${ }^{1}$

\begin{tabular}{|c|c|c|c|c|c|c|c|c|}
\hline \multirow[b]{3}{*}{ Variable } & \multicolumn{4}{|c|}{ Hunter-gatherers $(\mathrm{n}=10)$} & \multicolumn{4}{|c|}{ Farmers $(\mathrm{n}=10)$} \\
\hline & \multicolumn{2}{|c|}{ Top } & \multicolumn{2}{|c|}{ Bottom } & \multicolumn{2}{|c|}{ Top } & \multicolumn{2}{|c|}{ Bottom } \\
\hline & Mean & SD & Mean & $\mathrm{SD}$ & Mean & $\mathrm{SD}$ & Mean & $\mathrm{SD}$ \\
\hline $\begin{array}{l}\text { Total number of } \\
\text { features }\end{array}$ & 142.7 & 81.5 & 135.7 & 69.4 & 99.8 & 45.7 & 100.3 & 25.8 \\
\hline Mean number of pits & 69.5 & 53.6 & 63.3 & 40.6 & 38.8 & 19.4 & 50.5 & 15.7 \\
\hline $\begin{array}{l}\text { Mean number of } \\
\text { scratches }\end{array}$ & 73.2 & 32.7 & 72.4 & 33.7 & 61.0 & 25.4 & 49.8 & 17.5 \\
\hline Percent pits & 48.7 & 14.3 & 46.6 & 13.9 & 38.8 & 11.8 & 50.3 & 10.8 \\
\hline Mean pit length & 4.1 & 0.9 & 3.9 & 0.7 & 5.6 & 1.6 & 7.2 & 2.9 \\
\hline Mean pit width & 2.0 & 0.4 & 2.0 & 0.3 & 2.9 & 0.8 & 3.2 & 0.9 \\
\hline Mean scratch length & 25.2 & 6.8 & 27.9 & 8.5 & 30.4 & 10.8 & 39.0 & 11.0 \\
\hline Mean scratch width & 1.4 & 0.1 & 1.4 & 0.3 & 1.6 & 0.1 & 1.7 & 0.1 \\
\hline
\end{tabular}

${ }^{1}$ Top, top of facet; Bottom, bottom of facet.

TABLE 3. Within-samples comparison for stage one, with significant differences in bold ${ }^{1}$

\begin{tabular}{|c|c|c|c|c|c|c|}
\hline \multirow[b]{2}{*}{ Variable } & \multicolumn{3}{|c|}{ Hunter-gatherers } & \multicolumn{3}{|c|}{ Farmers } \\
\hline & $t$ & $\mathrm{df}$ & $P$ & $t$ & $\mathrm{df}$ & $P$ \\
\hline $\begin{array}{c}\text { Total number } \\
\text { of features }\end{array}$ & 0.615 & 9 & 0.554 & 0.945 & 9 & 0.369 \\
\hline $\begin{array}{l}\text { Mean number } \\
\text { of pits }\end{array}$ & 0.752 & 9 & 0.472 & -0.403 & 9 & 0.696 \\
\hline $\begin{array}{l}\text { Mean number } \\
\text { of scratches }\end{array}$ & 0.093 & 9 & 0.928 & 1.415 & 9 & 0.191 \\
\hline Percent pits & 0.458 & 9 & 0.648 & -2.359 & 9 & 0.043 \\
\hline Mean pit length & 1.473 & 9 & 0.175 & -1.294 & 9 & 0.228 \\
\hline Mean pit width & 0.049 & 9 & 0.962 & -0.745 & 9 & 0.476 \\
\hline $\begin{array}{l}\text { Mean scratch } \\
\text { length }\end{array}$ & -0.777 & 9 & 0.457 & 0.290 & 9 & 0.779 \\
\hline $\begin{array}{l}\text { Mean scratch } \\
\text { width }\end{array}$ & -0.379 & 9 & 0.713 & -0.441 & 9 & 0.669 \\
\hline
\end{tabular}

${ }^{1}$ Paired-samples $t$-test.

variations in pit frequency seem to be an important variable for detecting differences between the top and bottom of shearing facets (Robson and Young, 1990), between shearing and grinding facets (Teaford and Walker, 1984), and along the tooth row (Gordon, 1982; Mahoney, 2006). In each of these studies, an increase in pit frequency was related to an increase in compression. If the same interpretation is applied in the present study, then the greater frequency of pits at the bottom of the facet among farmers reflects relatively greater compression at that location. One reason for this may be that the microwear pattern mirrors the functional design of the molar. The bottom of the facet, toward the intercuspal fissure, is a location that is morphologically welldesigned to withstand high forces during chewing (Kehra et al., 1990). The intrafacet variation among early Neolithic farmers may therefore suggest a need to exert higher bite forces at the bottom of the facet, in a way that was not required during the earlier period.

Microwear did not vary over the facet among the hunter-gatherers (Table 3). The lack of variation suggests that the shearing and compressive forces that act upon facet nine do not necessarily predetermine microwear variations. One reason for this may be that facet nine, a grinding facet, unlike a shearing facet, does not have the same clear "leading" upper and "trailing" lower edge as it moves over the surface of the opposing molar during the chewing cycle. Perhaps this precludes biomechanicaly predetermined forces occurring at the upper and lower part of facet nine, in the way that it seems to on shearing facets from marsupials (e.g., Robson and Young, 1990).

Based on the results from the comparison between the samples in the first stage of the analysis, the bottom of the facet was chosen for stage two, because this dental location optimized the microwear variations between samples.

\section{Stage two}

Between samples. One discriminant function was calculated with an $\chi^{2}(2)$ of $14.656, P=0.002$, which indicated that the mean of the function was not equal across time periods. The function assigned $78 \%$ of the cases to the correct dietary group (hunter-gatherers $=76.9 \%$, farmers $=79.2 \%$ ). The high proportion of individuals correctly classified indicated that an increase in pit size and scratch width was a good combination of variables for emphasizing differences between the two groups. This interpretation was supported by the measures of variance $(\mathrm{U}=0.472 ; \mathrm{R}=0.621$ ) and the plot of the discriminant scores taken from each individual, which illustrated the good visual separation between hunter-gatherers and farmers. Based on the standardized canonical correlation coefficients, scratch width made the greatest contribution to the discrimination between the groups (pit width $=0.677$, pit length $=0.687$, scratch width $=$ 0.946). Table 5 provides descriptive statistics for the second stage of the analysis. Figure 4 is a plot of the discriminant scores and representative micrographs.

\section{DISCUSSION}

The increase in pit size suggests that the diet became harder during the Neolithic period (Table 5, Fig. 4). This result supports the idea that the early farmers relied more heavily on stone-ground plant foods (Wright, 1993). These tools were constructed from sandstone, limestone, and basalt, which contain particles of grit, like quartz inclusions, which are harder than enamel (Baker et al., 1959; Pough, 1996). More use of the tools might therefore have introduced more grit into the early Neolithic diet, producing a harder diet and larger pits (e.g., Pastor, 1993). The sheer volume of plant foods at Neolithic sites, like wheat, which can be processed with stone tools supports this interpretation (Galil et al., 1993; Garfinkel, 1987; Hillman, 1984, 1985). However, the width of pits 


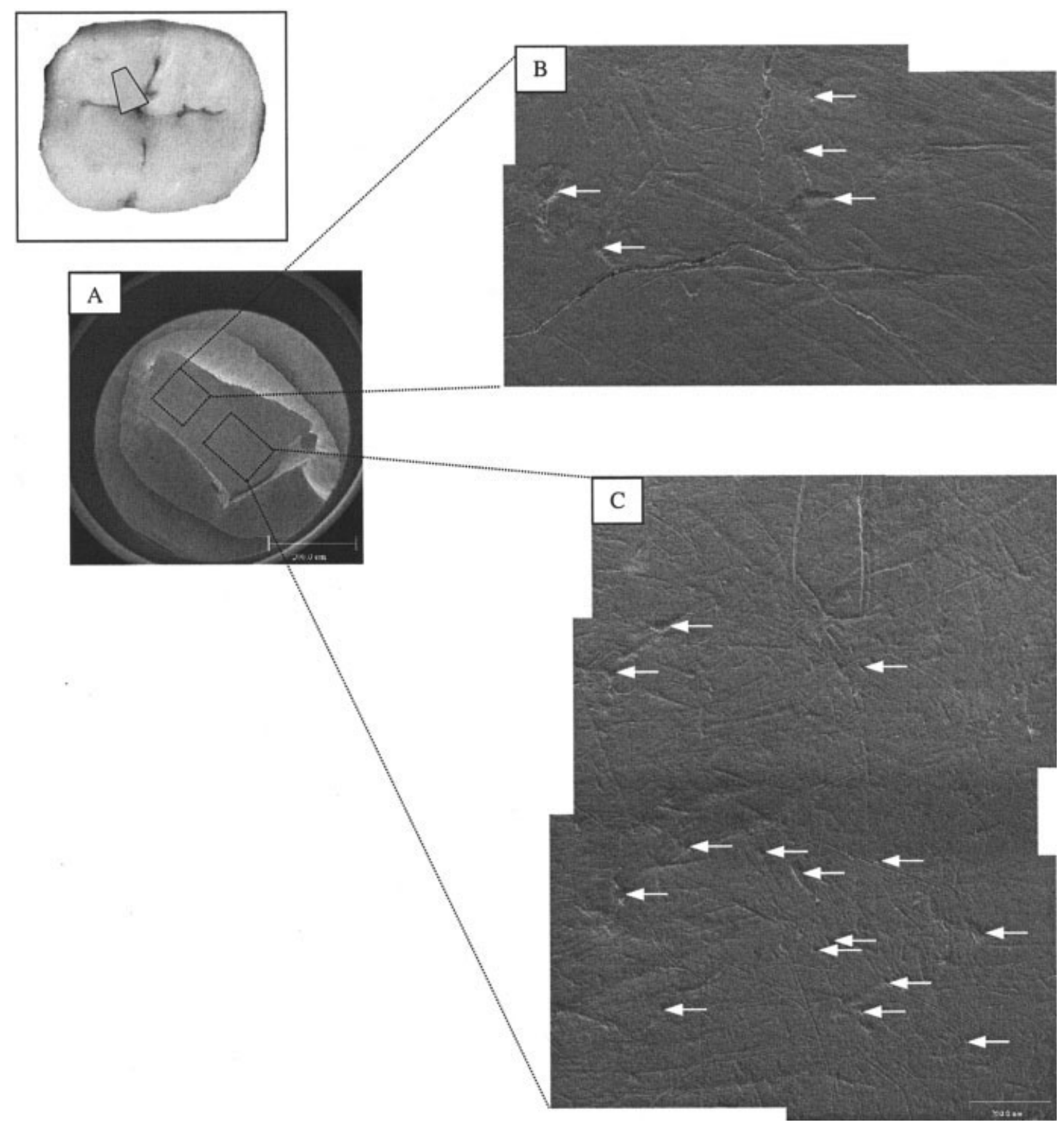

Fig. 3. Microwear at top and bottom of facet 9. A: Cast of facet 9 from second mandibular molar (inset), as seen on SEM viewing screen (magnification $20 \times$ ). B: A few dental pits at top of facet (arrows indicate pits). C: Increase in pit frequency at bottom of facet, compared to top. B and C are montages, created from several adjacent and overlapping micrographs. Each montage represents approximately $0.50 \mathrm{~mm}^{2}(\mathrm{~B})$ and $1 \mathrm{~mm}^{2}(\mathrm{C})$ of enamel surface. Micrograph magnification $=500 \times$, resolution $=3$, kilovoltage $=5$.

TABLE 4. Between-samples comparison for stage one, with significant differences in bold ${ }^{1}$

\begin{tabular}{|c|c|c|c|c|c|c|}
\hline \multirow[b]{2}{*}{ Variable } & \multicolumn{3}{|c|}{ Top of facet } & \multicolumn{3}{|c|}{ Bottom of facet } \\
\hline & $t$ & $\mathrm{df}$ & $P$ & $t$ & $\mathrm{df}$ & $P$ \\
\hline $\begin{array}{c}\text { Total number } \\
\text { of features }\end{array}$ & -1.424 & 18 & 0.174 & 2.170 & 18 & 0.096 \\
\hline $\begin{array}{l}\text { Mean number } \\
\text { of pits }\end{array}$ & -0.698 & 18 & 0.494 & 1.728 & 18 & 0.101 \\
\hline $\begin{array}{l}\text { Mean number } \\
\text { of scratches }\end{array}$ & -1.678 & 18 & 0.111 & 1.657 & 18 & 0.115 \\
\hline Percent pits & 0.880 & 18 & 0.391 & 0.960 & 18 & 0.350 \\
\hline Mean pit length & 0.660 & 18 & 0.518 & -4.457 & 18 & 0.000 \\
\hline Mean pit width & 0.424 & 18 & 0.667 & -4.430 & 18 & 0.000 \\
\hline Mean scratch length & -0.589 & 18 & 0.563 & -0.124 & 18 & 0.903 \\
\hline Mean scratch width & 0.764 & 18 & 0.460 & -2.691 & 18 & 0.015 \\
\hline
\end{tabular}

${ }^{1}$ Independent-samples $t$-test.
TABLE 5. Mean values and standard deviations (SD) for second stage of analysis ${ }^{1}$

\begin{tabular}{lccccr}
\hline & \multicolumn{2}{c}{$\mathrm{HG}(\mathrm{n}=30)$} & & \multicolumn{2}{c}{$\mathrm{F}(\mathrm{n}=30)$} \\
\cline { 2 - 3 } \cline { 5 - 6 } Variable & Mean & $\mathrm{SD}$ & & Mean & $\mathrm{SD}$ \\
\hline $\begin{array}{l}\text { Total number } \\
\text { of features }\end{array}$ & 166.5 & 22.5 & & 195.3 & 19.1 \\
$\begin{array}{l}\text { Mean number } \\
\quad \text { of pits }\end{array}$ & 85.0 & 12.4 & & 95.6 & 11.2 \\
$\begin{array}{l}\text { Mean number } \\
\quad \text { of scratches }\end{array}$ & 81.5 & 10.1 & & 99.7 & 8.1 \\
$\begin{array}{l}\text { Percent pits } \\
\text { Mean pit length }\end{array}$ & 51.0 & 15.1 & & 49.0 & 15.6 \\
Mean pit width & 4.7 & 1.8 & & 5.2 & 2.2 \\
Mean scratch length & 2.4 & 0.2 & & 2.5 & 0.1 \\
Mean scratch width & 23.8 & 8.6 & 26.1 & 8.8 \\
\hline
\end{tabular}

${ }^{1} \mathrm{HG}$, hunter-gatherer; F, farmer. 


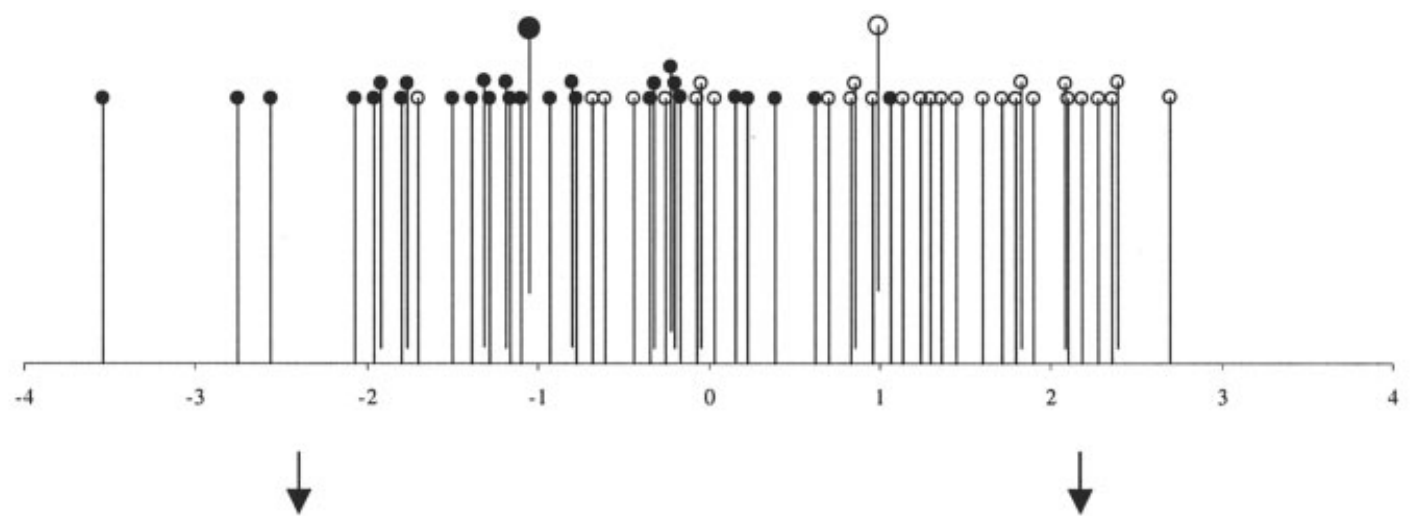

Hunter-gatherers $(\mathbf{O})$

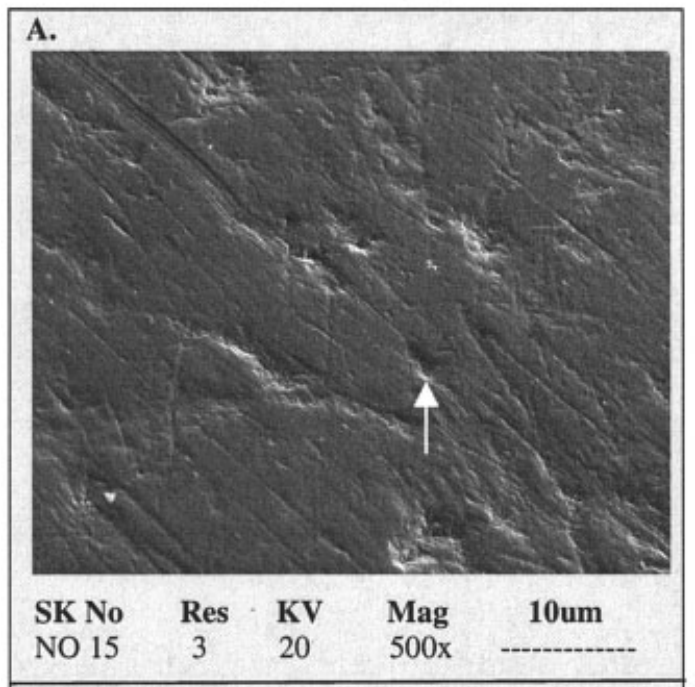

C.

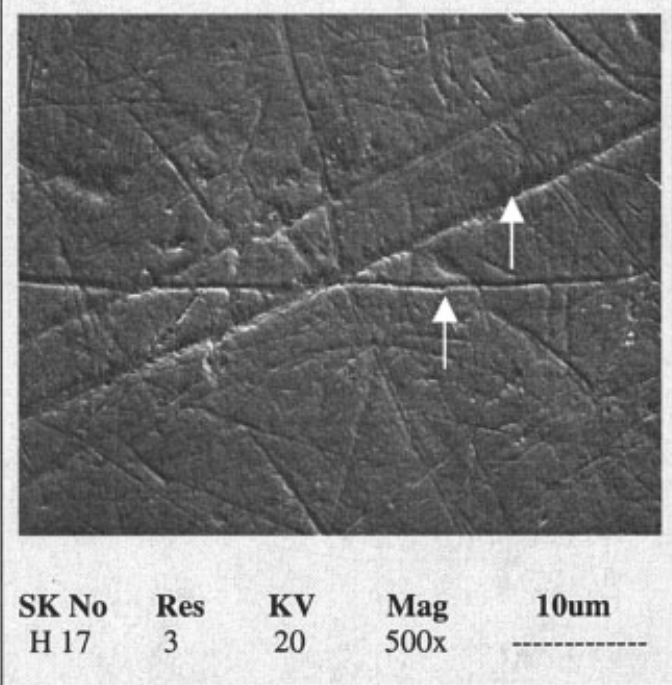

Farmers $(\mathrm{O})$

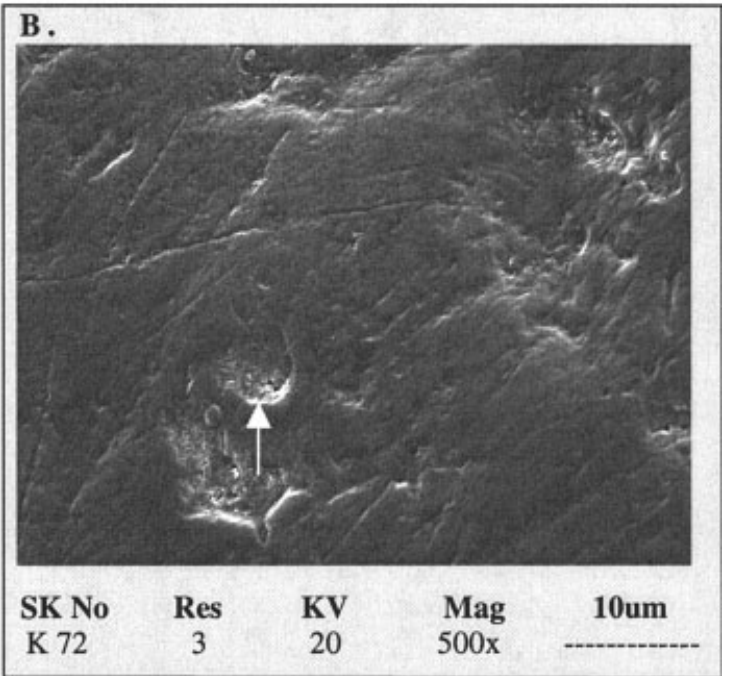

D.

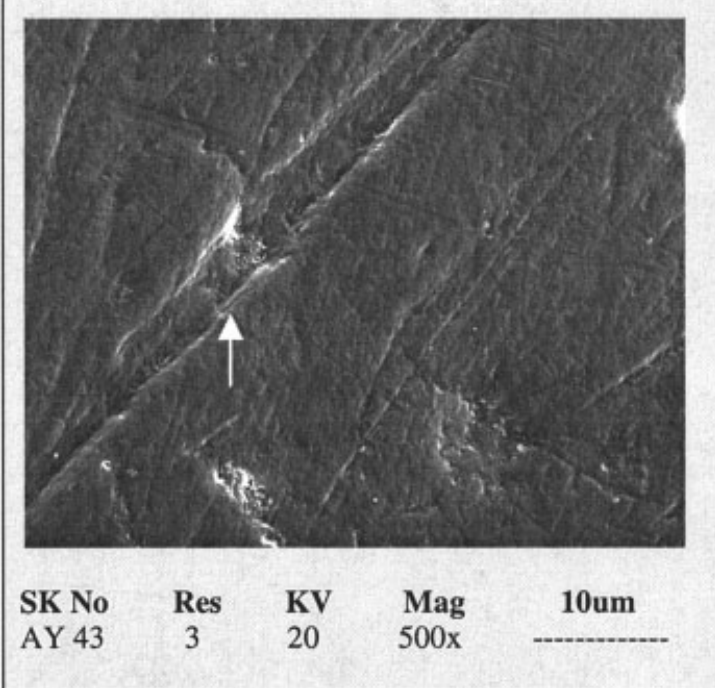

Fig. 4. Plot of discriminant function analysis. Plot illustrates discrimination between hunter-gatherers $(\bullet)$ and farmers $(\bigcirc)$, using combination of variables scratch width, pit width, and pit length. Large raised indicators (centroids) illustrate means of function for each group. Representative micrographs beneath plot illustrate difference in size of pits and scratches. A: Small (length and width) pits from hunter-gatherers (indicated by arrow). B: Large pits from agriculturalists (indicated by arrow). C: Narrow dental scratches from hunter-gatherers (indicated by arrows). D: Wide scratches from agriculturalists (indicated by arrow). NO 15, Nahal Oren skeletal number 15; K 72, Kfar Hahoresh skeletal number 72; H 17, Hayonim Cave skeletal number 17; AY 43, Atlit Yam skeletal number 3; Res, Resolution; KV, accelerating voltage. Magnification, $\times 500$ (original magnification); Size bar $=10 \mu \mathrm{m}$. 
from the farmers $(2.5 \mu \mathrm{m})$ does not suggest that the harder diet also led to more tooth-on-tooth contact.

The increase in scratch width during the Neolithic period is probably a result of the harder diet. Harder diets can require high bite forces (Lucas et al., 1994). A model of microwear formation processes developed in chimpanzees suggests that high bite forces, such as greater compression, might produce larger scratches (e.g., Gordon, 1982). Applying inferences gained from microwear research on chimpanzees to humans should not be problematic, given their similarities in enamel structure and the way that microwear responds to shear and compression (Boyde, 1989; Gordon, 1982; Mahoney, 2006).

The relationship between the width of the scratches and pits among hunter-gatherers and farmers suggests a similar causal agent (e.g., Teaford, 1993; Nystrom et al., 2004). The pits are not that much larger than the scratches (mean width of scratches $=58 \%$ of mean pit width among hunter-gatherers; mean width of scratches $=60 \%$ of mean pit width among farmers; Table 5). This relationship compares well to a study conducted by Teaford et al. (2001) on archaeological samples of modern humans, in which pits and scratches were attributed to the same cause (mean width of scratches $=34 \%$ of mean pit width in the prehistoric sample; mean width of scratches $=38 \%$ of pit width in the mission sample; data taken from Table 4.15 in Teaford et al., 2001). Therefore, perhaps dietary grit was an important cause of microwear in both periods.

While an increase in pit size across the two time periods was predicted, the decline in percentage of pits was not (Table 5). Yet studies on extant species showed that harder diets often generate more pits, not less. Unexpectedly, simple correlations indicate a significant negative relationship between the percentage and width of pits among hunter-gatherers (Pearson's $\mathrm{R}=-0.420 ; P=$ 0.021; Fig. 5) and farmers (Pearson's $\mathrm{R}=-0.463 ; P=$ 0.010; Fig. 6). As pit size increases in both groups, pit frequency decreases. One explanation for this relationship is that the frequency and size of pits might reflect a continuum during microwear formation processes (Fig. 7). As shear decreases and compression increases, features become shorter and wider, and are more likely categorized as a pit (Gordon, 1982). The point at which a feature is classified as a pit using a 4:1 ratio, rather than a scratch, produces an increase in pit frequency. As compression continues to increase hard particles are driven deeper into the enamel, and pit size increases (Ryan, 1979). Decreases in frequency might then occur as adjacent pits begin to merge. Under this hypothesis, the negative correlation between pit size and frequency among hunter-gatherers and farmers reflects increasing compression.

Most of the time, major differences in microwear occur during the transition to farming (e.g., Pastor, 1993). Yet here, there is some consistency between samples. Variation occurs between samples at the bottom of the facet, but not at the top (Table 4). One explanation is that microwear variation between samples reflects the functional design of the molar, just like the variation within samples (Table 3). Both patterns suggest that farmers exerted more compression at the bottom of the facet, toward the basin of the tooth, a location that is welldesigned for resisting such force. This interpretation is supported by the lack of variation between samples at the top of the facet (Table 4). The top of the facet, toward the cusp tip, is unsupported by the bulk of the tooth and less able to withstand high forces during chewing (e.g., Macho and Spears, 1999). If more bite force was required

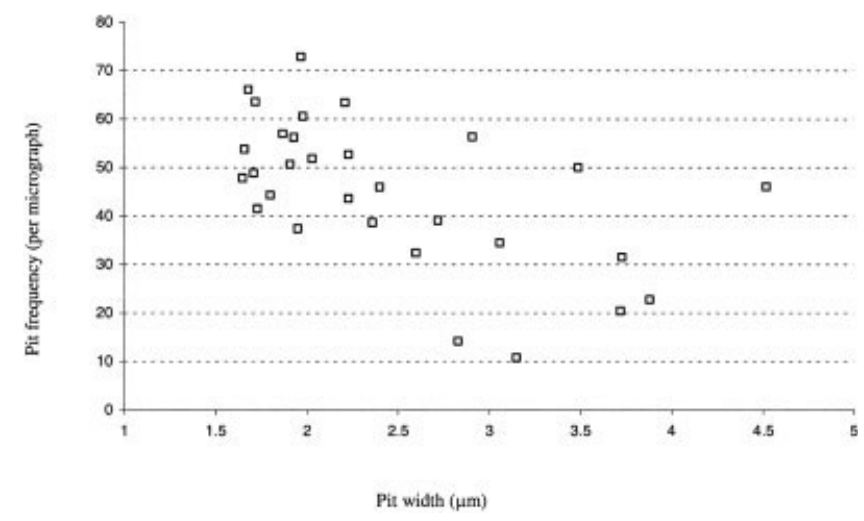

Fig. 5. Correlation between pit frequency and pit width among hunter-gatherers.

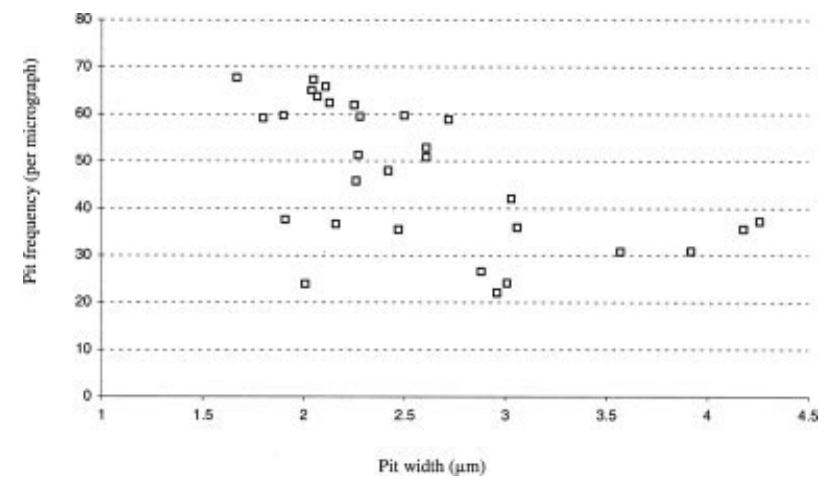

Fig. 6. Correlation between pit frequency and pit width among farmers.

by the Neolithic diet, then differences between Natufians and early farmers would not be expected at that dental location.

These results suggest that microwear analyses are capable of detecting subtle dietary developments with accompanying changes in mastication (i.e., more and less force) in a geographically localized area (i.e., northern Israel). This furthers our understanding about dietary hardness across the transition to agriculture, because it shows that an increased reliance on food processing does not necessarily produce a less resistant diet, which has been inferred from macrowear studies (e.g., Smith, 1984). Indeed, the results from the microwear analysis are incongruent with her study on hunter-gatherers and farmers. Smith (1984, p 54) attributed differences in macrowear between such economies to less resistant foods during the Neolithic period due to a greater reliance on grinding stones and pottery for food preparation. The archaeological periods chosen for the present study were prepottery periods. Therefore, perhaps the introduction of pottery in the study area would also have led to a softer diet. Indeed, previous microwear research inferred that the introduction of pottery can have a profound effect on dietary hardness (Molleson et al., 1993).

\section{CONCLUSIONS}

The aim of this study was to infer dietary texture from dental microwear during the Natufian to early Neolithic 
A.
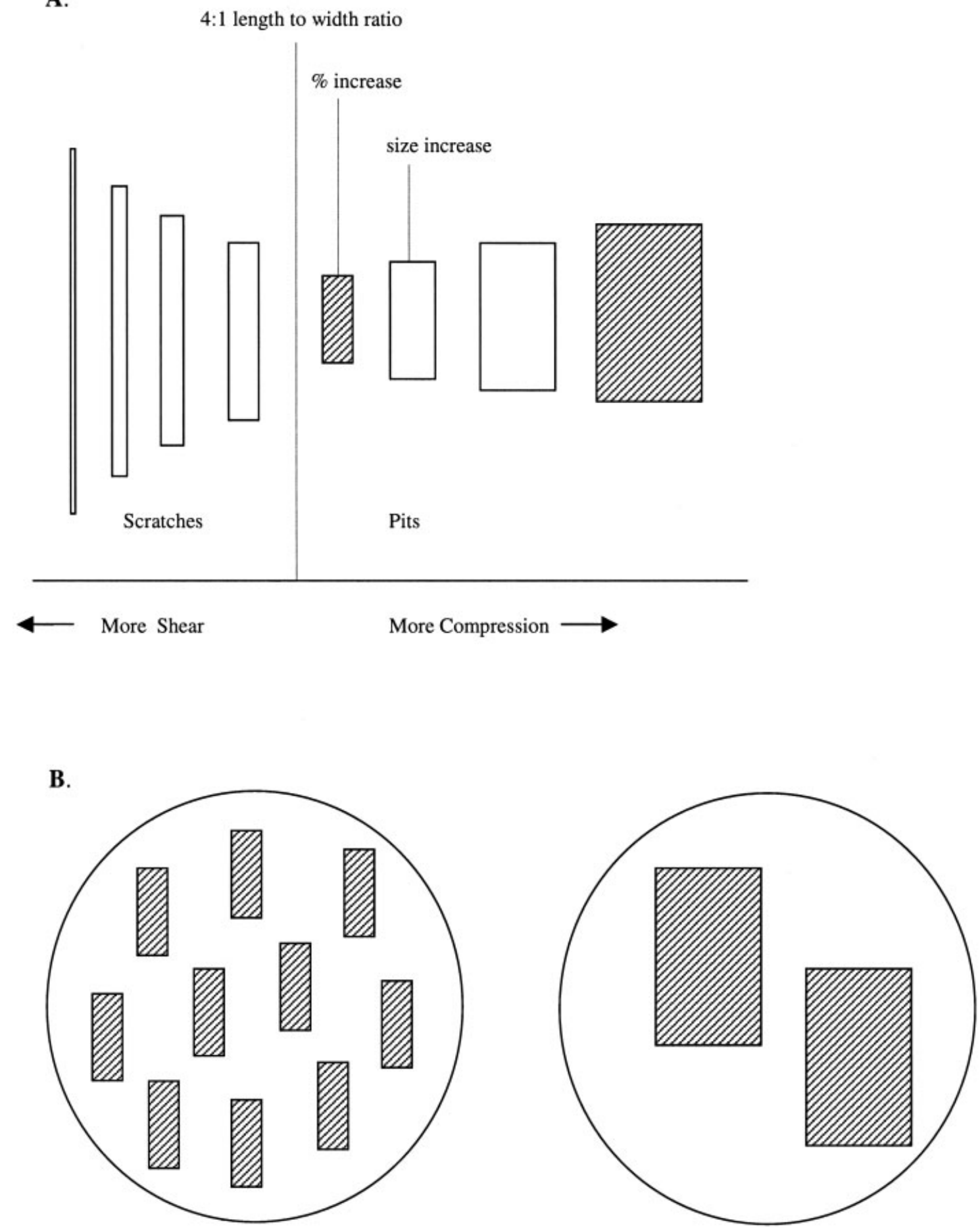

Fig. 7. Model of microwear formation processes. A: Relationship between microwear features and type of force acting on tooth surface. B: Relationship between number and size of dental pits on micrograph.

development in northern Israel. The microwear pattern suggested that the diet became harder during the Neolithic period, and this was related to the archaeological evidence. It was inferred that grit from plant-grinding stone tools was primarily responsible for microwear variations between hunter-gatherers and early farmers. Further conclusions are that microwear on facet nine may reflect the functional design of the molar, and it may therefore be possible to exploit this in diet-microwear analyses.

\section{ACKNOWLEDGMENTS}

I thank the two anonymous reviewers and the editor for their helpful comments, and Baruch Arensberg and Israel Hershkovitz at the Sackler School of Medicine, 
Tel Aviv University, for allowing access to samples in their care.

\section{LITERATURE CITED}

Baker G, Jones LHP, Wardrop ID. 1959. Cause of wear in sheeps' teeth. Nature 184:1583-1584.

Bar Yosef O. 1991. The archaeology of the Natufian layer at Hayonim Cave. Int Monogr Prehist Archaeol Ser 1:81-92.

Bar Yosef O. 1992. The Neolithic period. In: Ben-Tor A, editor. The archaeology of ancient Israel. Open University. Yale University Press. p 10-39.

Bar Yosef O. 1993. Hayonim cave. In: Lewinson-Gilboa A Aviram J, editors. The new encyclopedia of archaeological excavations in the Holy Land, II. New York: Simon and Schuster. p 590-591.

Bar Yosef O. 1998. The Natufian culture in the Levant: threshold to the origins of agriculture. Evol Anthropol 6:159-77.

Bar Yosef O, Belfer-Cohen A. 1989. The origin of sedentism and farming communities in the Levant. J World Prehist 3:447498.

Blaeuer MW, Rose JC. 1982. Bioarchaeology of the Powell Canal site. In: House JH, editor. Powell Canal. Arkansas Archaeological Survey publication no. 19. Fayetteville: Arkansas Archaeological Survey. p 72-84.

Boyde A. 1989. Enamel. In: Berkovitz BKB, Boyde A, Frank RM, Höhling HJ, Moxham BJ, Nalbandian J, Tonge CH, editors. Teeth: handbook of microscopic anatomy (volume, V/6). New York: Springer Verlag. p 309-407.

Bullington J. 1991. Deciduous dental microwear of prehistoric juveniles from the lower Illinois Valley. Am J Phys Anthropol 84:59-73.

Clutton-Brock J. 1971. The primary animals of the Jericho tell from the proto-Neolithic to the Byzantine period. Levant $3: 41-55$.

Colledge S. 1994. Plant exploitation on epi-Palaeolithic and early Neolithic sites in the Levant. Ph.D. thesis, University of Sheffield.

Covert HH, Kay RF. 1981. Dental microwear and diet: implications for determining the feeding behaviors of extinct primates, with a comment on the dietary pattern of Sivapithecus. Am J Phys Anthropol 55:1-36.

Eisenmann DR. 1998. Enamel structure. In: Cate AR, editor. Oral histology. Development, structure and function. 5th ed. St. Louis: Mosby-Year Book, Inc. p 218-235.

Eshed V, Gopher A, Gage TB, Hershkovitz I. 2004a. Has the transition to agriculture reshaped the demographic structure of prehistoric populations? New evidence from the Levant. Am J Phys Anthropol 124:315-329.

Eshed V, Gopher A, Galili E, Hershkovitz I. 2004b. Musculoskeletal stress markers in Natufian hunter-gatherers and Neolithic farmers in the Levant: the upper limb. Am J Phys Anthropol 123:303-315.

Every RG. 1974. Thegosis in prosimians. In: Martin RD, Walker A, Doyle GA, editors. Prosimian biology. London: Duckworth. p 579-620.

Galil E. 1993. Atlit: prehistoric site on the sea floor. In: Lewinson-Gilboa A, Aviram J, editors. The new encyclopaedia of archaeological excavations in the Holy Land, I. New York: Simon and Schuster. p 120-122.

Galil E, Weinstein-Evron M, Hershkovitz I, Kislev M, Lernau O, Kolska-Horwitz L, Lernau H. 1993. Atlit-Yam: a prehistoric site off the Israel coast. J Field Archaeol 20:133-156.

Garfinkel Y. 1987. Yiftahel: a Neolithic village from the seventh millennium B.C. in lower Galilee, Israel. J Field Archaeol 14:199-212.

Garfinkel Y. 1993. Yiftahel. In: Lewinson-Gilboa A, Aviram J, editors. The new encyclopaedia of archaeological excavations in the Holy Land, IV. New York: Simon and Schuster. p 1511-1512.

Garrod DAE. 1957. The Natufian culture: the life and economy of a Mesolithic people in the Near East. Proc Br Acad 43:211227.
Gopher A. 1997. Horvat Galil-an early PPNB site in the upper Galilee, Israel. Tel Aviv 24:183-222.

Gordon KD. 1982. A study of microwear on chimpanzee molars: implications for dental microwear analysis. Am J Phys Anthropol 59:195-215.

Gordon KD. 1986. Dental microwear analysis to detect human diet. Am J Phys Anthropol 69:206-207.

Goring-Morris N. 1995. Investigations at an early Neolithic settlement in the lower Galilee: results of the 1991 season at Kfar Hahoresh. Atiqot 27:37-62.

Goring-Morris N. 2000. The quick and the dead. The social context of aceramic Neolithic mortuary practices as seen from Kfar Hahoresh. In: Kuijt I, editor. Life in Neolithic farming communities. New York: Kluwer Academic/Plenum Publishers. p 103-136.

Grine FE. 1981. Trophic differences between "gracile" and "robust" australopithecines: a scanning electron microscope analysis of occlusal events. S Afr J Sci 7:203-230.

Grine FE. 1987. Quantitative analysis of occlusal microwear in Australopithecus and Paranthropus. Scan Microsc 1:647-656.

Grine FE, Kay RF. 1987. Early hominid diets from quantitative image analysis of dental microwear. Nature 333:765-768.

Gügel IL, Grupe G, Kunzelmann KH. 2001. Simulation of dental microwear: characteristic traces by opal phytoliths gives clues to ancient human dietary behavior. Am J Phys Anthropol 114:124-138.

Harmon AM, Rose JC. 1988. The role of dental microwear analysis in the reconstruction of prehistoric diet. In: Kennedy BV, LeMoine GM, editors. Diet and subsistence: current archaeological perspectives. Calgary: Archaeological Association of the University of Calgary. p 267-272.

Henry DO. 1989. From foraging to agriculture. The Levant at the end of the Ice Age. Philadelphia: University of Pennsylvania Press.

Hershkovitz I, Galil E. 1990. 8000 year-old human remains on the sea floor near Atlit, Israel. J Hum Evol 5:319-358.

Hershkovitz I, Gopher A. 1988. Human burials from Horvat Galil: a pre-pottery Neolithic site in the upper Galilee, Israel. Paleorient 14:110-125.

Hershkovitz I, Garfinkel Y, Arensburg B. 1986. Neolithic skeletal remains at Yiftahel, area C. Paleorient 12:73-81.

Hillman G. 1984. Traditional husbandry and processing of archaic cereals in modern times: part I, the glume wheats. Bull Sumer Agric 1:114-152.

Hillman G. 1985. Traditional husbandry and processing of archaic cereals in recent times: part II, the free-threshing cereals. Bull Sumer Agri 2:1-31.

Hopf M, Bar Yosef O. 1987. Plant remains from Hayonim Cave. Paleorient 13:117-120.

Kay RF, Hiiemae K. 1974. Jaw movement and tooth use in recent and fossil primates. Am J Phys Anthropol 40:227-256.

Kenyon K. 1957. Excavations at Jericho. Palestine Explor Q 3:67-82.

Khera SC, Carpenter CW, Staley RN. 1990. Anatomy of cusps of posterior teeth and their fracture potential. J Prosthet Dent 64:139-147.

King T, Aiello LC, Andrews P. 1999. Dental microwear of Griphopithecus alpani. J Hum Evol 36:3-31.

Lalueza C, Pérez-Pérez A. 1993. The diet of the Neanderthal child Gibraltar 2 (Devil's Tower) through the study of the vestibular striation pattern. J Hum Evol 24:29-41.

Lalueza C, Pérez-Pérez A, Turbon D. 1996. Dietary inferences through buccal microwear analysis of Middle and Upper Pleistocene human fossils. Am J Phys Anthropol 100:367-387.

Legge A. 1996. The beginning of caprine domestication in Southwest Asia. In: Harris DR, editor. The origins and spread of agriculture and pastoralism in Eurasia. London: UCL Press. p 238262.

Lucas P, Peters CR, Arrandale SR. 1994. Seed-breaking forces exerted by orangutans with their teeth in captivity and a new technique for estimating forces in the wild. Am J Phys Anthropol 94:365-378.

Macho GA, Spears IR. 1999. Effects of loading on the biomechanical behavior of molars of Homo, Pan, and Pongo. Am J Phys Anthropol 109:211-227. 
Mahoney P. 2003.Human dental microwear in Natufian huntergatherers and pre-pottery Neolithic agriculturalists from northern Israel. Ph.D. dissertation, University of Sheffield.

Mahoney P. 2006. Brief communication: intertooth and intrafacet dental microwear variation in an archaeological sample of modern humans from the Jordan Valley. Am J Phys Anthropol 129:39-44

Maier W, Schneck G. 1982. Functional morphology of hominoid dentitions. J Hum Evol 11:693-696.

Martin L. 1994.Hunting and herding in a semi-arid region: an archaeological and ethnological analysis of the faunal remains from the epi-Palaeolithic and Neolithic of the eastern Jordan steppe. Ph.D. dissertation, University of Sheffield.

Mellaart J. 1975. The Neolithic of the Near East. London: Thames and Hudson.

Mills JR. 1955. Ideal dental occlusion in the primates. Dent Pract 6:47-63.

Molleson T, Jones K. 1991. Dental evidence for dietary change at Abu Hureyra. J Archaeol Sci 18:525-539.

Molleson T, Jones K, Jones S. 1993. Dietary change and the effect of food preparation on microwear patterns in the Late Neolithic at Abu Hureyra, northern Syria. J Hum Evol 24:455-468.

Moore AMT. 1982. The first farmers in the Levant. In: Young TC, Smith P, Mortensen P, editors. The hilly flanks and beyond: essays on the prehistory of southwestern Asia. Studies in ancient civilization, no. 36. Chicago: Oriental Institute. p 91-112.

Moss-Salentijn L, Hendricks-Klyvert M. 1990. Dental and oral tissues. 3rd ed. Baltimore: Williams and Wilkins.

Norusis MJ. 1991. The SPSS guide to data analysis for SPSS/ PC+. 2nd ed. Chicago: SPSS, Inc.

Norusis MJ. 1993. SPSS for Windows professional statistics release 6.0. Chicago: SPSS, Inc.

Noy T. 1989. Some aspects of Natufian mortuary behaviour at Nahal Oren. BAR Int Ser 508:53-58.

Noy T. 1993. Nahal Oren. In: Lewinson-Gilboa A, Aviram J, editors. The new encyclopaedia of archaeological excavations in the Holy Land, II. New York: Simon and Schuster. p 1167-1170.

Noy T, Higgs E. 1971. Raqefet cave. Israel Explot J 21:225-226.

Noy T, Legge AJ, Higgs ES. 1973. Recent excavations at Nahal Oren, Israel. Proc Prehist Soc 39:75-99.

Nystrom P, Phillips-Conroy JE, Jolly CJ. 2004. Dental microwear in anubis and hybrid baboons (Papio hamadryas, sensu lato) living in Awash National Park, Ethiopia. Am J Phys Anthropol 125:279-291.

Pastor R. 1993. Dental microwear among prehistoric inhabitants of the Indian subcontinent: a quantitative and comparative analysis. Ph.D. dissertation. University of Oregon at Eugene.

Pérez-Pérez A, Lalueza C, Turbon D. 1994. Intraindividual and intragroup variability of buccal tooth striation pattern. Am J Phys Anthropol 94:175-187.

Pérez-Pérez A, Espurz V, de Castro JMB, de Lumley MA, Turbón D. 2003. Non-occlusal dental microwear variability in a sample of Middle and Late Pleistocene human populations from Europe and the Near East. J Hum Evol 44:497-513.

Perrot J. 1960. Excavations at Eynan (Ein Mallaha). Preliminary report on the 1959 season. Isr Explor J 2:14-22.

Perrot J. 1993. Enan. In: Lewinson-Gilboa A, Aviram J, editors. The new encyclopaedia of archaeological excavations in the Holy Land, III. New York: Simon and Schuster. p 389-393.

Peters C. 1982. Electron-optical microscope study of incipient dental microdamage from experimental seed and bone crushing. Am J Phys Anthropol 57:283-301.

Piperno DR. 1988. Phytolith analysis: an archaeological and geological perspective. San Diego: Academic Press.

Pough FH. 1996. Rocks and minerals. New York: Houghton Mifflin Co.

Puech PF. 1976. Recherche sur le mode d'alimentation des hommes du Paleolithique par l'étude microscopique des couronnes dentaires. In: de Lumley H, editor. La préhistoire Française I. Paris: Centre National de la Recherche Scientifique. p 708-709.

Puech PF. 1992. Microwear studies of early African hominid teeth. Scan Microsc 6:1083-1088.
Puech PF, Albertini H, Serratrice C. 1983. Tooth wear and dietary patterns in early hominids from Laetoli, Hadar and Olduvai. J Hum Evol 12:721-729.

Rensberger JM. 1978. Scanning electron microscopy of wear and occlusal events in some small herbivores. In: Butler PM, Joysey KA, editors. Development, function and evolution of teeth. London: Academic Press. p 415-437.

Rensberger JM. 2000. Pathways to functional differentiation in mammalian enamel. In: Teaford M, Meredith Smith M, Ferguson MWJ, editors. Development, function and evolution of teeth. Cambridge: Cambridge University Press. p 252-268.

Robson SK, Young WG. 1990. A comparison of tooth microwear between an extinct marsupial predator, the Tasmanian tiger Thylacinus cynocephalus (Thylacinidae) and extant scavenger, the Tasmanian devil Sarcophilus harrisii (Dasyuridae: Marsupialia). Aust J Zool 37:575-589.

Rollefson G, Kohler-Röllefson I. 1989. The collapse of early Neolithic settlements in the southern Levant. BAR Int Ser 508:73-90.

Ryan A. 1979. Wear striation direction on primate teeth. Am J Phys Anthropol 50:155-168.

Schmidt CW. 2001. Dental microwear evidence for a dietary shift between two nonmaize-reliant prehistoric human populations from Indiana. Am J Phys Anthropol 114:139-145.

Sillen A. 1981. Strontium and diet at the Hayonim Cave. Am J Phys Anthropol 56:131-137.

Sillen A. 1986. Dietary reconstruction and Near Eastern archaeology. Expedition 28:16-22.

Smith BH. 1984. Patterns of molar wear in hunter-gatherers and agriculturalists. Am J Phys Anthropol 63:39-56.

Smith P. 1972. Diet and attrition in the Natufians. Am J Phys Anthropol 37:233-238.

Smith P, Bar-Yosef O, Sillen A. 1984. Archaeological and skeletal evidence for dietary change during the late Pleistocene/ early Holocene in the Levant. In: Cohen MN, Armelagos GJ, editors. Palaeopathology at the origins of agriculture. New York: Academic Press. p 101-136.

Steckelis M, Yizraely T. 1963. Excavations at Nahal Oren. Preliminary report. Isr Explor J 13:1-12.

Strait S. 1993. Molar microwear in extant small-bodied faunivorous mammals: an analysis of feature density and pit frequency. Am J Phys Anthropol 92:63-79.

Tabachnick BG, Fidell L. 2001. Using multivariate statistics. 4th ed. Needham Heights, MA: Allyn and Bacon.

Teaford MF. 1985. Molar microwear and diet in the genus Cebus. Am J Phys Anthropol 66:363-370.

Teaford MF. 1991. Dental microwear: what can it tell us about diet and dental function? In: Kelley MA, Larsen CS, editors. Advances in dental anthropology. New York: Alan R. Liss. p 341-356.

Teaford MF. 1993. Dental microwear and diet in extant and extinct Theropithecus: preliminary analyses. In: Jablonski NG, editor. Theropithecus: the life and death of a primate genus. Cambridge: Cambridge University Press. p 331-349.

Teaford MF, Lytle JD. 1996. Brief communication: diet-induced changes in rates of human tooth microwear: a case study involving stone-ground maize. Am J Phys Anthropol 100:143-147.

Teaford MF, Oyen OJ. 1989. Differences in the rate of molar wear between monkeys raised on different diets. J Dent Res 6:1513-1518.

Teaford MF, Runestad JA. 1992. Dental micowear and diet in Venezualan primates. Am J Phys Anthropol 88:347-364.

Teaford MF, Walker A. 1983. Dental microwear in adult and still born guinea pigs (Cavia porcellus). Arch Oral Biol 28:1077-1081.

Teaford MF, Walker A. 1984. Quantitative differences in dental microwear between primate species with different diets and a comment on the presumed diet of Sivapithecus. Am J Phys Anthropol 64:191-200.

Teaford MF, Maas M, Simons, EL. 1996. Dental microwear and microstructure in early Oligocene primates from the Fayum, Egypt: implications for diet. Am J Phys Anthropol 101:527-543.

Teaford MF, Larsen CS, Pastor RF, Noble VE. 2001. Pits and scratches. Microscopic evidence of tooth use and masticatory behaviour in La Florida. In: Larsen CS, editor. Bioarchaeology of La Florida: human biology in the northern frontier New Spain. Gainesville: University Press of Florida. p 82-112. 
Ungar PS. 1992. Feeding behavior and dental microwear in Sumatran anthropoids. Ph.D. dissertation, State University of New York at Stony Brook.

Ungar PS. 1994. Incisor microwear of Sumatran anthropoid primates. Am J Phys Anthropol 94:339-363.

Ungar PS. 1996. Dental microwear of European Miocene catarrhines: evidence for diets and tooth use. J Hum Evol 31:355-366.

Ungar PS. 1997. Microware 3. http://comp.uark.edu/ pungar/

Ungar PS, Grine FE. 1991. Incisor size and wear in Australopithecus africanus and Paranthropus robustus. J Hum Evol 20: 313-340.

Ungar PS, Spencer MA. 1999. Incisor microwear, diet, and tooth use in three Amerindian populations. Am J Phys Anthropol 109:387-396.

Valla FR, Khalaily H, Samuelian N, Bocquentin F, Delange C, Valentin B, Plisson H, Rabinovitch R, Belfer-Cohen A. 1998. Le Natoufien final et les nouvelles fouilles à Mallaha (Eynan), Israel, 1996-1997. Mitekufat Haeven 28:105-176.

Walker A. 1979. SEM analysis of microwear and its correlations with dietary patterns. Am J Phys Anthropol 50:489.
Walker A. 1984. Mechanisms of honing in the male baboon canine. Am J Phys Anthropol 65:47-60.

Walker A, Teaford M. 1989. Inferences from quantitative analysis of dental microwear. Folia Primatol (Base1) 53:177-189.

Walker A, Hoeck HN, Perez L. 1978. Microwear of mammalian teeth as an indicator of diet. Science 201:908-910.

Willcox G. 1998. Archaeobotanical evidence for the beginnings of agriculture in Southwest Asia. In: Damania AB, Valkoun J, Willcox G, Qualset CO, editors. The origins of agriculture and crop domestication. Aleppo, Syria: ICARDA. p 25-38.

Willcox G. 1999. Agarian change and the beginnings of cultivation in the Near East: evidence from wild progenitors, experimental cultivation and archaeobotanical data. In: Godsen C, Hather J, editors. The prehistory of food: appetites for change. London: Routledge. p 478-500.

Wright K. 1993. Early Holocene ground stone assemblages in the Levant. Levant 25:93-111.

Zar JH. 1999. Biostatistical analysis. 4th ed. Upper Saddle River, NJ: Prentice Hall. 